\title{
Hacia la construcción del patrimonio católico nacional: piedad popular y tradición en el Perú moderno y republicano, 1821-1840.
}

Patrimonio, en su acepción más tradicional, significa "legado de nuestros padres", haciendo referencia a las nociones de herencia y paternidad. Es la herencia que hemos recibido de nuestros ancestros, que viene de una época pasada, y que se constituye en un legado que asegura el recuerdo de nuestra familia'. No sería sino hasta el advenimiento de la llustración, en el siglo XVIII, que la mentalidad racional, en plena crítica a la tradición y la religión, le daría al patrimonio una dimensión semántica más extensiva, incursionando en la esfera de lo público. El patrimonio era ahora una herencia pública. $Y$ no de individuos exclusivamente, sino que sobre todo de la Nación ${ }^{2}$. El Estado pasó a apropiarse del discurso patrimonial, y como bien se ha señalado el patrimonio nunca más abandonó el discurso estatal, como esencial para producir la conciencia de la Nación. Así el Estado produjo y reprodujo un discurso en torno al patrimonio de la Nación, donde se reivindicaba la existencia de un legado, material y espiritual, que podía remontarse a miles y miles de años. El patrimonio, como

\footnotetext{
1 Andre DESVALLEES, "A l'origine du mot patrimoine". Dominique POULOT (Ed.) Patrimoine et modernité (Chemins de la mémoire), Paris, L'Harmattan 1998, pp. 89-106; Henry Pierre JEUDY (Ed.). Patrimoines en folie, Paris, Editions de la Maison des Sciences de l'homme 1990.

2 Daniel J. GRANGE y Dominique POULOT, L'esprit des lieux. Le patrimoine et la cite, Grenoble, PUG 1997, pp. 331 y ss.
}

herencia de la nación, era parte de la memoria colectiva social.

Ahora bien, la religión, que antes del triunfo de la razón, se consideraba la depositaria de la tradición y de la herencia del pasado, tuvo que dejar espacio a las construcciones patrimoniales que se fueron cimentando, no sólo del Estado, sino también de la familia, grupos o clases $^{3}$. Pero a la larga la modernidad permitió que la Iglesia (Católica en nuestro caso), ensayara formas de penetración y presencia en tal espacio. El rostro visible y cotidiano de la esfera de lo religioso, produjo discursos patrimoniales, que en América Latina apuntaló al estructurado por el Estado. Al menos eso es lo que creemos. Precisamente en esta oportunidad busco explorar ese ángulo para nuestro país. Dado que el análisis de esta hipótesis carece aún de estudios que lo aborden al detalle, mi incursión será tentativa. Concretamente, propondré cómo en la Iglesia Católica se produjo desde los inicios de la República no solamente el afán de afirmar los lazos de unión con el nuevo Estado, tal y como se había hecho en la Colonia, sino sobre todo y

\footnotetext{
3 Fue Maurice HALBWACHS, Les cadres sociaux de la mémoire, Paris, PUF 1952, quien llamó la atención sobre la importancia de las construcciones de diversas "memorias" sociales como el de la familia. Y Pierre BOURDIEU, La distinction. Paris. Minuit 1979, quien sistematizó mejor esta idea, usando sus propias calegorias de análisis.
} 
ante los cambios sociales y políticos producidos, y el interés del Estado en ir afirmando un discurso patrimonial, buscará sobre sus bases ideológicas de tradición y conservadurismo, construir también un discurso patrimonial alterno profundamente afirmativo de su identidad, usando como insumo la propia tradición y como vehículo la piedad. A partir de alli ofreceré algunas consideraciones generales acerca de la relación que existe entre el patrimonio y lo religioso en la sociedad peruana.

\section{La Iglesia: discurso nacional y objetivos comunes}

El Estatuto provisional dado por el general San Martín (1821), primer documento del Estado naciente, fue claro en señalar que la religión católica era la religión oficial del Perú y del Estado, y que era obligación de éste defenderla y conservarla en sus dogmas fundamentales ${ }^{4}$. En este punto fue claro el interés de mantener el carácter católico del Estado y en términos teóricos de la nación, "el Perú católico por instituciones y por hábitos" como diría el secretario de estado José de Morales, en 1827, no podía ceder en este punto, coincidiendo tanto liberales como Manuel_Lorenzo Vidaurre hasta eclesiásticos conservadores como el obispo José Sebastián de Goyeneche o el clérigo Mateo Aguilar, para quienes esa necesidad era de importancia radical para el correcto desenvolvimiento de la fe y de la sociedad peruanas ${ }^{5}$. Si era una Iglesia dominada íntegramente por el Estado, o no, era un agregado que sólo reforzaba o flexionaba tal situación. Políticos civiles como eclesiásticos participaron de esta fuerte relación de Iglesia y Estado que sintetizaba al Perú y producía "la sabiduría y las luces" como expresó el presbítero Mariano José de Arce en la oración por la jura del Estatuto Provisorio 6. Una Iglesia protegida que participara al lado de

\footnotetext{
${ }^{4}$ PAZ SOLDAN, Op. Cit, p. 415.

${ }^{5} \mathrm{Cl}$. Jose de MORALES. Exposición del secrelario de Estado del Despacho de Negocios Eclesiásticos al Congreso Constituyente de 1827. Lima, Imp. de La Libertad 1827, p. 5: M.L. VIDAURAE, Proyeclo de Código Eclesiástico, París, Imp de Julio Didot 1830, Archivo Vargas Ugarle - AVU. Manuscritos. T. 17, núm. 77. Cana de Goyeneche a Leon XII; J.M. AGUILAR, AVU. T. 20 , num 42 Recurso de J.M. Aguilar al soberano congreso sobre circulacion de libros pro. hibidos y libertinaje de prensa

6 Mariano José de ARCE, Oración pronunciada el dia 8 de oclubre en celebridad del Juramento del Estatuto Provisorıo del Perú, Lima, Imp. Peña 1821. p. 13
}

ella en la constitución de la nacionalidad "de modo que logre la nación por este medio toda la felicidad a la que aspira"7.

Esto ciertamente fue de la mano de una política profundamente regalistas por parte del Estado, y basta para ello solo anotar las disposiciones de San Martín y su Junta Purificadora del Clero, la reforma de regulares de 1826 o las actitudes de algunos ministros regalistas en los años posteriores. Pero no implicó que la actitud de la Iglesia se divorciara de su común interés con el Estado en mantener el "sosiego de la sociedad". Antes bien, atacó puntualmente a sus detractores, procurando en todo momento insistir en los lazos que la unían al Estado y los fines comunes a los que estaban llamados ${ }^{8}$.

Ese estado, por otro lado, estaba inserto en un proceso por cimentar por todos los medios, de las manos de las elites políticas, un discurso nacional. Los actuales estudios en las áreas del teatro republicano, la música y el periodismo y otros más nos dan luces de este esfuerzo por producir y reproducir un discurso nacional, basado en los ideales de unión, lucha por la libertad, y sobre todo de legitimidad del Estado en tanto representante de una sociedad entroncada con el pasado. La nación era una construcción ciudadana, con sus objetivos, pero que estaba anclada en el pasado. Tenía su origen en los antiguos "peruanos" -también ellos tenían ese nombre-. Había pues un continúo histórico que era imperioso rescatar. $Y$ en ese sentido las apelaciones a imágenes de incas y guerreros imperiales no eran gratuitas, buscaban imprimirle un sello distintivo a la nación. Recordemos, por ejemplo, el lugar que ocupó Huayna Cápac en el Canto a Junín de Olmedo. O las alusiones clásicas que el himno, las proclamas independentista y las de la república temprana enfatizan (Grecia, Roma) uniéndolas a las alusiones locales (Saña, Pachacámac). No solamente demostraba este interés por el pasado, sino por insertar ese pasado, del país, en el

\footnotetext{
7 Archivo Arzobispal de Lima - AAL. SCSG. Leg 5. Años 1826-1829. Cana de J.L. Mariátegui a Carlos Pedemonte, del 23-XI-1827.

${ }^{8}$ Biblioteca Nacional - BN. Manuscritos. D 11691 Cartas de Fr Felipe Gonzales at obispo Goyeneche y Barreda Chibay, marzo de 1826; Coleccion Documenta sobre la Independencia del Perú - COIP, Vol. XV. Tomo I, p. 173: Raphael M. TAUREL, De la liberté religieuse au Pérou considérée dans ses rapports avec lemigrations étrangére, Paris, Chez C. Maillet-Smichtz 1851, pp. 105-109.
} 
concierto global del pasado de la humanidad. La nación peruana era particular pero dentro del tejido universal. Nacionalismo y modernidad se dieron la mano en las propuestas simbólicas de las elites politicas afincadas en el novísimo Estado.

Desde ese punto de vista resultaba más que evidente el interés de ese Estado por una construcción nacional con proyección histórica. El decreto del 28 de agosto de 1821, al mes de proclamada la independencia, estableció la Biblioteca Nacional. "El establecimiento de una Biblioteca Nacional es uno de los medios más eficaces para poner en circulación los valores intelectuales y hacer que los hombres de todas las edades se comuniquen reciprocamente los secretos que han escudriñado en el fondo de la naturaleza". También se pensó en erigir un Museo Nacional, para los objetos de la antigüedad del Perú, pedagogía visual a las que todos los ciudadanos debian acceder. Quedó evidenciado por un decreto de Tagle y Monteagudo dado el de abril de 1822. El decreto también prohibió extraer antigüedades de las huacas y comerciar con ellas fuera del país, en un claro interés por preservar la herencia local. También un Museo de Historia Natural, Antigüedades, Historia y Curiosidades Artísticas fue establecido en 1826 bajo la dirección de Mariano Eduardo de Rivero. Llegó a contener objetos de animales, mineralógicos, históricos, arqueológicos y curiosidades artísticas. Eran evidencias del interés nacional por mostrar a la sociedad y al mundo su pasado y la relación de ella con su presente. La pedagogía patrimonial, aún y a pesar de guerras civiles y de lo inestable de estas fundaciones, procuró articularse desde los primeros años republicanos.

\section{Piedad popular y Tradición: bases para la construcción de un patrimonio nacional católico}

De allí precisamente que desde el inicio el Estado consciente de su rol, se esforzó porque en la simbología pública nacional, en construcción, hubiese un gran espacio para lo religioso. No solo declaró el Congreso en 1823

9 Decreto del 8-11-1822 que se hacía indigno del nombre de peruano el que no fuera religioso, detallando al mínimo el ritual de las fiestas de asistencia oficial. Si no que, por iniciativa del legislador Faustino Sánchez Carrión, dispuso el 22 de mayo del mismo año que se hiciesen rogativas en todas las iglesias de la República por la salud del país, mientras el 22 de setiembre se declaró a la Virgen Santísima de las Mercedes, patrona de las armas nacionales. $Y$ el Congreso constituyente de 1828 , por ley, firmada por el Presidente José de la Mar y el regalista ministro Francisco Javier Mariátegui, eligió como Patrono de la República a San José. Como bien dijo el documento de la constitución de 1823, al invocar en sus primeras palabras, "el nombre de Dios, por cuyo poder se instituyen todas las sociedades y cuya sabiduría inspira a los legisladores", era imposible prescindir de la Iglesia y su religión en la construcción del Perú.

La relación entre Estado e Iglesia, estuvo pues muy presente en los aspectos más nimios de la vida urbana nacional, así el decreto del 11 de noviembre de 1839 mandó reglamentar el repique de campanas, no solamente para los ritos propiamente religiosos, sino también para los patrios: repiques generales en los aniversarios de las batallas de Junín, Ayacucho y Ancash, en los días de los patronos de la República y en los de las armas del Estado. Se harían los repiques a las $6 \mathrm{am}, 12 \mathrm{~m}$, y $7 \mathrm{pm}$, con una duración de quince minutos cada una. Además, fue autorizado el repique general cuando la Nación celebrase algún acontecimiento especial y de regocijo público, previa autorización gubernamental. Ese mismo año, el reglamento de Policia para Lima y su provincia, tuvo normas sobre el castigo a quienes transgredieran la religión del Estado, la moral y la salubridad públicas, que con algunas modificaciones, subsistió hasta 1877.

El fervor popular, en Lima y provincias, era entonces muy intenso en la vida de la Iglesia. En Lima, cada mañana, al dar un cuarto para las nueve, la campana de la Catedral sonaba, el tráfico se interrumpía y se arrodillaban los transeúntes. Lo mismo ocurría entre las seis y siete de la tarde, al escucharse el toque de oración con tres campanas suaves en la Catedral, repetidas en todas las Iglesias. Luego 
de la interrupción era cortés decir "buenas noches" o esperar que un hombre de más edad lo pronunciara. A la diez de la noche cesaban los ruidos de la ciudad, excepto cuando el sereno de cada barrio daba la hora con las palabras: "Ave María Purísima ¡Viva el Perú y sereno!" Era la frase que resonaba en las calles. Alli se sintetizaba el cambio ocurrido con la llegada de la República y sus afanes nacionales. Estos cambios igualmente se observaban en algunos ritos, como la navidad, que era una fiesta pública y de los hogares, donde la gente solía recorrer en Lima los nacimientos armados por algunas familias modestas y otras acomodadas, y donde se empezó a adornar también, junto al pequeño Jesús en su pesebre, con algunas piezas de artesanía local que representaban a indigenas ofrendando bienes al Señor recién nacido. Estos nacimientos, con la figura de Jesús, los animalitos, pastores y Reyes Magos, llamaron siempre la atención de los extranjeros por su ingenio y costo ${ }^{10}$.

En el campo de la música, la profana o popular se habia expandido bastante en las misas y demás ritos al interior de las parroquias, catedrales y monasterios, ocupando espacios antes reservados para la música litúrgica en el gusto de elites y del pueblo". Incluso muchos párrocos de pueblos apoyaban manifiestamente las fiestas populares en los ritos y fiestas eclesiásticas. En ciudades como Lima, en momentos como las procesiones de Cuasimodo, en las parroquias no criollas había un gran despliegue profano. Ello venía desde la colonia, sin duda, pero había aumentado bastante durante la independencia, al punto de incluso relajar la mirada de la alta jerarquia ${ }^{12}$. Los géneros musicales eran diversos y a veces las letras mostraban un cierto tufillo nacionalista, sobre todo, cuando, en las fiestas de la patria, se hacia énfasis a la concordia, a la unidad, a la felicidad. E incluso, cuando en procesiones y otras manifestaciones

\footnotetext{
10 Jose Maria OLANCO. Diario de viaje del Presidente Orbegoso al sur del Peru Lima, Instiluto Riva - Agüero 1974. Tomo I. p. 285-286: Max RADIGUET. Lima y la sociedad peruana. Lima, Biblioteca Nacional del Peru 1971, p. 29 Cambios que se aprecian igualmente en el terreno simbolico-urbanistico: Ia segunda plaza de la ciudad, de la Inquisición, con la República se llamara Conslilucion. Era un gran mercado. con carnicerias, y en los bordes, puestos de pescado. O el antiguo Palacio de la Inquisicion, que se convierle en deposito y prision, o la Universidad de San Marcos, en su Aula Magna, que recibe al Congreso Nacional

11 BLANCO, Op. Cit, Tomo I, pp. 70-71 y Tomo II, pp. 285-286

12 Que habia tratado de combatirlo, en una perspecliva muy ilustrada, durante el siglo XVIII, por lo menos desde el plano del discurso
}

allende los templos era posible las arengas e intromisiones verbales más arriesgadas. Ciertamente dependía mucho del contexto político y el ánimo de la feligresía. Hacia mediados de siglo, recién encontramos un serio intento de la jerarquía por controlar estos desbordes y por incluso restringir la música profana en los ambientes religiosos, aunque curiosamente desde 1840 en forma definitiva su misma música litúrgica dejó de ser centro de atracción y espectáculo en beneficio de otros centros seculares de la sociedad ${ }^{13}$. Siendo apoyados en esta ofensiva por el discurso intelectual de algunos laicos, en un deseo particular por cerrar filas ante cualesquiera formas de música popular consagrada, considerada bárbara de por $\mathrm{si}^{14}$.

Hubo al lado de estas manifestaciones estatales o populares, que consciente o inconscientemente llevaban a una unidad de acción de Iglesia y Estado, en pro de la nación, voces más bien individuales, como la del mulato José Manuel Valdés, limeño, nacido en 1767, educado por agustinos, con dispensa real médico titulado, miembro de la Sociedad Patriótica y poeta que en 1821 y 1823 cantó a la independencia y libertad. En 1833 publicó su Salterio Peruano, paráfrasis de 150 salmos de David y otros textos líricos bíblicos, para estimular la piedad popular. En 1840, y ante la declaración de bienaventurado de fray Marín de Porres, editó un libro sobre la vida del santo, mulato y de orígenes humildes como él ${ }^{15}$. Desfasado en sus conocimientos, una nota suya sobre la mortalidad de Lima, provocó ataques periodísticos en 1843. Murió ese año. José Joaquín Larriva, clérigo limeño, cultivó el periodismo, la sátira política y la prosa y verso. En el Fusilico del General Flores (1828), haciendo uso de conversaciones burlescas, arremetió contra el general Juan José Flores, famoso por sus proclamas anti peruanas, con un tinte plagado de naciona-

\footnotetext{
13 AAL. Causa de Curatos. Legajo 22. 1832-33. Ica. Exp. 22-XXXVII. Tambièn Juan Carlos ESTENSSORO, Musica y Sociedad Coloniales. Lima 1680-1830. Lima, Colmillo Blanco 1989. p. 65.

14 Ct al respecto M.L. VIDAURRE, Plan del Perú, Lima 1971, p. 28; Juan de ARONA, Diccionario de peruanismos, Lima 1974, Tomo I, p. 110. Para cues. liones leóricas, Cecilia MENDEZ, "República sin Indios: la comunidad imagina del Perú", Henrique URBANO (Compilador). Tradición y Modernidad en los Andes. Cusco, CBC 1992. y Juan Carlos ESTENSSORO, "Modernismo, estética, música y fiesta: elites y cambio de actitud frente a la cultura popular. Perú 1750-1850", Idem.

15 Vida admirable del Bienaventurado Fr. Martin de Porres, Lima 1840.
} 
lismo exaltado, típico de un momento de crisis en las relaciones con la Gran Colombia. Es interesante como usó de la risa y la burla para difundir un credo nacional ${ }^{16}$. Manuel Bañón, música, compositor y director de orquesta, también fue parte de este grupo de exaltadores del discurso nacional. Tuvo una academia de música en el convento de San Agustín, de 1830 a 1832, dedicándose luego a la dirección musical del Teatro, para reabrir su escuela conventual en 1847 y 1852. Logró la dirección de la Sociedad Filarmónica Santa Cecilia en 1856, al igual que el de maestro de capilla de la Iglesia de San Agustín. Entre su abundante producción musical bueno es rescatar el "Nuevo Himno Patriótico" (1828), de sabor popular y de claro interés nacional; "La nueva canción de la Chicha" (1836), obra indudablemente compuesta para ser preferida por el pueblo en chicherías, picanterias y chinganas, además de otros espacios de diversión. Intento de síntesis de la nación mestiza, criolla y urbana. $Y$ por sobre todo el famoso "El ataque de Uchumayo", fragmento de un romancero lírico popular con olor de patria nacional, que ha pervivido hasta la actualidad en las bandas de guerra y música de institutos militares y centros escolares de provincias y de Lima.

Pero deciamos que más allá del alma intelectual, el tejido imbricado entre nación e Iglesia, entre Estado e Iglesia, con sus obvias connotaciones patrimoniales, se van tejiendo a la luz de los rituales y las pompas que el catolicismo hace gala. En el Cuzco la gran procesión del Señor de los Temblores era un momento para que las altas jerarquías civiles y eclesiásticas se unieran alrededor del ritual de un Señor que era objeto de misa solemne con los alcaldes, prefecto, y militares presentes, que luego recorría la ciudad, en andas y cargado por los miembros de las instituciones republicanas representativas, que provocaba histeria y dolor en los miles de ojos campesinos y de mistis que lo observaban, y que luego, bajo su gran atuendo, en la noche, al entrar en la Catedral, se arrodillaban ante él, la patria reunida a sus

16 "Coleccion de las producciones en prosa y verso serias, jocosas y satiricas. de Larriva", en Manuel de ODRIOZOLA, Colección de documentos literarios del Perui, Lima 1864, volumen II. pies $^{17}$. Dos meses después de Semana Santa, la fiesta del Corpus, antes centro de la vida religiosa colonial, decaía en beneficio de una procesión más unificadora ${ }^{18}$. No tan lejos de allí la peregrinación al Qollor Rity, motivaba grandes movilizaciones humanas, esta vez sobre todo de campesinos, oriundos de las comunidades cercanas, ritual con olor a incienso cristiano y también a tradiciones ancestrales. En Arequipa, las celebraciones religiosas también tuvieron como centro la Semana Santa, celebraciones en el ámbito urbano, de raigambre más criolla, distintas a la de los pueblos del Callejón de Colca, donde los frailes franciscanos, encargados de las parroquias de Yanque, Chivay y Coporaque, trataron de perennizar la mixtura de tradiciones andinas y españolas, sintetizadas en las fiestas de Semana Santa y sobre todo en la devoción mariana a las Candelarias ${ }^{19}$. Esta devoción también lo podemos apreciar en las fiestas y procesiones de las vírgenes de Caima, Characato y Quilca, cuyos días centrales, 2 de febrero, congregaba a multitud de fieles, de sus localidades y de otros territorios aledaños. $Y$ ciertamente en la fiesta de Nuestra Señora de Chapi, promovida de una manera entusiasta por los padres franciscanos, encargados de la capilla desde 1795, y que en su fiesta del 2 de febrero empezó a atraer a peregrinos regionales desde entonces ${ }^{20}$. En Puno, la fiesta de la Virgen de la Candelaria produjo igualmente más peregrinos y el regocijo de un pueblo, con sus autoridades al frente, en el calor de la procesión, de

\footnotetext{
17 BLANCO, Op. Cit., Tomo I, p. 286: Paul MARCOY, "Cuzco (1846)", Raúl PORRAS BARRENECHEA, Antologia del CuzCO, Lima, Fundación Bustamante de la Fuente 1992, pp. 217-224: SARTIGUES, Op. Cit., pp. 175-176. Dice Sir Clements Markham, "Primero iba un regimiento de soldados, seguido por los miembros de la Corte Suprema de Justicia, los esludiantes de los colegios, lodas las ordenes religiosas, el dean y el capitulo. Enseguida... Nuestro Señor de los Temblores". Clements R. MARKHAM, Cuzco and Lima, Petroperú y Markham College 2001. p. 151. Mientras el viajero Charles Wiener argumentaba: "Esta procesion es considerada la fiesta principal del Cuzco; vienen indios de los alrededores... siguen la marcha los alumnos del seminario con sus vestidos de corte sacerdotal; les siguen una compañia de soldados que a su vez precede at Prefecto, a todas las autoridades, a los tribunales en ropa de gala y al capitulo... vienen enseguida los indios". Charles WIENER. Perú y Bolivia, Lima, Instituto Frances de Estudios Andinos - Consejo Nacional de Ciencia y Tecnologia - Universidad Nacional Mayor de San Marcos 1993, pp. 338-344. 18 BLANCO, Op. Cit, Tomo II, p. 191; E. George SQUIER, Un viaje por tierras incaicas (1863-1865), Lima, Universidad Nacional Mayor de San Marcos 1974, p. 247.

19 La Virgen de Coporaque fue tallada en tiempos del Virrey Toledo, la de Chivay en 1700, y las de Yanque y Cabanaconde en 1803. A inicios del siglo $\mathrm{XIX}$, si bien los tranciscanos habian perdido las cabezas de parroquias de Yanque y Cabanoconde, detentando la de Chivay todavia, su influencia de raigambre colonial seguia siendo fuerte en toda la región.

20 Alejandro MALAGA NÚÑEZ-ZEBALLOS. Historia de la Virgen Candelaria en el Obispado de Arequipa, siglos XVI-XX, Arequipa, Universidad Católica de Santa Maria 2000.
} 
los discursos inflamados o sencillamente en la participación muda.

En la costa la fiesta de Nuestro Señor de Luren tuvo un impacto muy fuerte en Ica, la Ica criolla y mestiza, de grandes haciendas y pequeñas poblaciones. El origen de la peregrinación y procesión se remonta a 1570 y el traslado de una imagen de Cristo a la doctrina de Santiago de Luren (o Lurin Ica), por obra de los franciscanos, quienes aquí también fomentan esta devoción, como mecanismo de evangelización ${ }^{21}$. Ya para la República la devoción está muy asentada, más allá de los indígenas iqueños, y había calado en el conjunto de la población mestiza y criolla, mayoritaria por lo demás $^{22}$. El 30 de mayo de 1831, tras un terremoto muy fuerte, la imagen del Señor de Luren es llevada de su capilla a la Plaza Mayor de la ciudad en una gran peregrinación penitencial ${ }^{23}$. Desde entonces, tanto en Jueves Santo y en Octubre -su fiesta- este ritual, como el del Señor de los Temblores, Chapi, La Candelaria, y otros se repite: procesión multitudinaria, y protocolo de las altas autoridades y comunión general alrededor del mundo de lo sacro. Como en Lima, y la devoción del Señor de los Milagros, que en estos años, y allí están desde los informes de los viajeros, las guías de forasteros, hasta las acuarelas de Pancho Fierro, dándonos noticias, es una devoción multitudinaria, y ocasión de penitencia popular. Por supuesto en todos los casos, es un esquema de participación, vía la pompa y el protocolo, casi idénti-

\footnotetext{
21 La talla fue pedida a la doctrina por fray Francisco de Madrigal, porque los frailes del Convento de Lima no la querian, al ser parte de unos bienes pedidos para el Convento a España, pero que habian naufragado y estaban deteriora. dos. Archivo del Convento de San Francisco - ACSF. Registro 31. $n^{\circ} 31$

22 Con el tiempo se labró una historia distinta sobre el origen de la talla: seria un inglés o alemán "muy católico", que por la persecución protestante, decidió embarcarla a América, al Callao, pero por una tormenta llegó a Pisco, y desem. barcada intentó ser llevada a lomo de mula a Lima, pero se perdió y fue a parar a Lurin-Ica, de donde no se movió, con lo cual los pobladores procedieron a levantarle una capilla en aquél lugar. Testimonio de Alberto Casavilca Curaca. Archivo del Patronato de Ica. API. Papeles Varios: Señor de Luren. Este relato, a todas luces contrapuesto a la realidad de los hechos, del cual el testimonio de Francisco de Madrigal es la mejor prueba, tiene mucha semejanza al de otros relatos de devociones: la de la Virgen de Caima, dice que unos arrieros trans. portaban al Cuzco tres imágenes "probamente donadas por Carlos $v$ " pero en el lugar actual la caja con la imagen se abrió y "decidio" quedarse en el lugar. La de Chapi dice que unos arrieros "de paso probable a Charcas" pasaron por alli y olvidaron una caja con la imagen de la Virgen, la cual encontrada por lugareños, empezó a ser venerada. Alejandro MALAGA, Op. Cit.. pp. 41-42 y 69. Mulas, imágenes que se pierden y devociones "queridas" por esas Virgenes y Cristos, en tal o cual lugar, saltan de inmediato. Cabria la pregunta si los tranciscanos, presentes en esas tres zonas en algún momento histórico, lo labraron como mecanismo de catequesis.

23 Antonio UNZUETA ECHEVARRIA, La Orden del Carmen en la Evangelización del Perú. San Sebastián y Vitoria, La Obra Máxima y El Carmen, voIumen II, p. 168.
}

co, pero rescatamos la dimensión de aglutinar más y más al conjunto de sus poblaciones regionales, y sobre todo de ser una ocasión para las autoridades locales, en reafirmar sus compromisos ciudadanos y mostrar con las elites regionales su unidad con la Iglesia. Y, para la jerarquía eclesiástica, la oportunidad de reafirmar sus lazos con ese Estado.

Al lado de ellos la santidad que atrae miradas y que posibilitan nuevas exteriorizaciones de un patrimonio nacional católico en construcción, es la de San Martín de Porres, la del Padre Guatemala y la Beatita de Humay. De algunos de ellos hablaremos.

Aquí el tema se cruza, con ideas ya revisadas líneas atrás: tras la partida de los jesuitas en el siglo XVIII, la crisis del clero secular y la acefalía más o menos evidente de las diócesis peruanas tras la independencia y durante varios años después, y por obra de las políticas desamortizadoras que afectaron mucho a algunas ordenes especialmente -las hospitalarias, la Merced, los Agustinos- son los franciscanos los que, a pesar de también verse afectados por todo lo anterior, tuvieron una pastoral muy activa y casi monopólica en su presentación pública, hasta 1850 por lo menos. No debe pasar desapercibido para nosotros el hecho de devociones estimuladas en Luren y Chapi en las primeras décadas del siglo ${ }^{24}$. Tampoco olvidar que esa ofensiva coincidió con su consolidación en el trabajo de selva. En Ocopa, se abrió el Colegio de Propaganda Fidei (1836), seguido por la llegada de un buen grupo religiosos franciscanos, en 1838, para las misiones. El Arzobispo Benavente había encargado al franciscano español afincado en Bolivia, Andrés Herrero captar religiosos en Europa para la empresa. Llegaron 80 religiosos -para Chile, Perú y Bolivia-, 19 para las misiones peruanas, básicamente italianos y españoles. El Estado trató de justificar este apoyo a los franciscanos, pues "la civilización de las tribus salvajes del interior i de su reducción a la santa fe católica, es una empresa digna de las luces del siglo I

\footnotetext{
24 También el hecho de que la reforma de regulares de 1826, les permitió, a contrapelo de la misma ley, mantener varios conventos dentro de una misma región.
} 
aceptada a los ojos del todopoderoso"25. Obviamente hubo oposición de algunos liberales, que vieron un peligro para la nacionalidad la llegada de esos extranjeros, particularmente españoles, pero a la larga contribuyeron aquellos en el fortalecimiento de los objetivos geopoliticos y de avances de las fronteras del pais ${ }^{26}$. Pedro Gual fue uno de esos recién llegados, emigrado político catalán, y refugiado en los Estados Pontificios. La instalación de la Propaganda Fidei, para la propagación del evangelio entre los infieles de América del Sur, en la diócesis de Maynas en 1840, tuvo como su gran divulgador a su obispo el franciscano José María de Arriaga ${ }^{27}$. Nuevos vientos sonaban pues en la Iglesia, con el creciente protagonismo franciscano.

En 1839 había muerto en medio de honores fúnebres pomposos y olor de santidad, el franciscano fray Ramón Rojas de Jesús María, llamado el padre Guatemala. Nacido en aquél lugar de Centroamérica, los acontecimientos políticos de índole marcadamente liberal y secular de su gobierno, le llevaron a este franciscano a migrar al Perú en abril de 1831. Era pues un celoso defensor de las prerrogativas eclesiásticas. Se alojó en el convento de los suyos en Lima y en el Callao erigió el hospital e Iglesia de Nuestra Señora de Guadalupe. En 1835 se fue a Chincha y en abril estaba en Ica -todo el sur costeño desde Lurín Lima a Ica estaba bajo la influencia misionera franciscana-. Allí erigió la Casa de Ejercicios de San Francisco y reparó el templo de Jesús, Maria y José, con un letrerito que decía a la entrada: "Dios te mira, el tiempo pasa, la muerte viene, la eternidad espera"28. Con ayuda legal del Presidente Felipe Santiagc Salaverry (1835-1836), construyó un cementerio para, entre otros, enterrar pobres, por el pago de un pequeño arancel. Quiso el dictador nom-

\footnotetext{
25 Pilar GARCIA JORDAN, Cruz y Arado, fusiles y discursos. La construcción de los orientes en el Peru y Bolivia 1820-1840. Lima. Instiluto Francés de Estudios Andinos e Instituto de Estudios Peruanos 2001, p. 93; Tambièn Julián HERAS, El convento de los Descalzos de Lima Lima, Convento de los Descalzos 1995 y Odorico SAIZ, Restauración de la Orden franciscana en el Peru en el siglo XIX. Lima, Provincia Franciscana de San Francisco Solano 1995.

26 Raphael M. TAUREL, Colección de obras selectas del clero contemporáneo del Peru, Paris. Mezin 1853-5, tomo I., pp. 284-285.

27 Jose Maria de ARRIAGA, Institución de la Propaganda de la Fe y de la civi. lización entre los infieles de América Meridional establecida en la capital del Perú el 2 de Julio de 1840. Lima 1840. Por ley de 1831, su sede ya no estuvo en Maynas sino en Chachapoyas.

28 La reparación fue hecha entre 1836 y 1838 , y básicamente consistió en una fachada nueva. Se reparo de nuevo el templo en 1868, tras el terremoto de ese año e igual en 1898 y 1919. En la ciudad de Ica puede visitarse actualmente.
}

brarlo obispo de Maynas, pero los acontecimientos políticos de su muerte (1836) lo impidieron. Famoso por su ayuda a los pobres, y su espíritu casi eremita, en Ica fueron famosas sus visitas a enfermos y menesterosos, sus visitas apostólicas a los pueblos del departamento, su interés en reparar los templos y fundar una casa de educandas ${ }^{29}$. De hecho erigió en Pisco, el hospital femenino de Guadalupe. Decían que tenía dotes extraordinarios, vaticinaba acontecimientos, se mortificaba, y prefería a los pobres y a los niños. Músico, pintor y literato: compuso versos religiosos, trisagios, oraciones y novenas, y transcribió un extracto del Tratado de la usura de Guillermo Peraldo ${ }^{30}$. Murió el 23 de julio de 1839, a los 63 años ${ }^{31}$.

29 Es interesante cómo reparó muchos templos del valle e incluso cambió el nombre a algunos poblados, todo esto dentro de sus misiones populares 0 incursiones catequéticas. Saraja Chiquitin se convierte en San Joaquin. Arataya en Santa Rosa, Cerro Prieto en Guadalupe, y empieza a levantar la Iglesia de San Antonio (Pueblo Nuevo), terminada en 1895, la de San Juan de los Molinos y la de El Carmen. En cuanto al Cementerio fue destruido en el siglo XX. para construir otro, actualmente en uso.

30 La obra está inédita en el Archivo Arobispal de Lima y parece que el misionero queria obtener licencias para publicarlo. También redactó una novena sobre la vida de San Francisco Solano, reproducida por su biógrafo el franciscano Perruquet en La Voz de San Jeronimo (Ica). probablemente redactado antes de su venida al Perú. Enrique TOVAR, El Apóstol de Ica, Fr. José Ramón Rojas (El Padre Guatemala), Lima, Compañia de Impresiones y Publicidad 1943. p. 253. Era además un buen devoto de la Virgen de Guadalupe, como puede verse en sus obras, pintando incluso varios lienzos, uno de los cuales se encuentra en Lima en el Convento de Los Descalzos y otro en la Iglesia de San Francisco de Ica. Se dice incluso que el Altar de la Iglesia Matnz del Callao, en honor a Guadalupe, es obra suya [Cf. Fotos].

31 Sobre su muerte puede leerse El Comercio, Lima, 5-VIII y 6-VIII-1839. Sostenemos que la devoción por este misionero nació y fue estimulada por los franciscanos del lugar y de Lima. El médico que lo inhumó se llevó un pedazo de rodilla, unos huesos de los dedos y otros más para su culto personal. Desde el Arzobispado se inició el proceso de recolección de información y testimonios para su Causa y encargado fue uno de sus devotos, el sacerdote secular Mateo Tordoya -hermano del obispo y politico Pedro José Tordoya., quien en 1870 exhumó el cadáver encontrando que, aparte del médico, en 1861 el cura del Templo de Jesús y Maria -donde estaba y está enterrado- y otras personas clandestinamente exhumaron el cadáver y se llevaron más huesos y retazos del habito. Tovar levantó muchos testimonios que lo ubicaban como un santo. aunque sin ningún hecho milagroso de relevancia. También recuperó los huesos perdidos. Parece que en 1898 el proceso se paralizó y los cuadernos de la Causa (testimonios) se perdieron. TOVAR, Op. Cit, pp. 271-272; El Comercio, Lima, 23-XII-1870. Es interesante como a partir de estos testimonios, posteriormente, se siguió construyendo la figura del Venerable. Según uno de ellos, un franciscano, con quien caminaba de lca a Pisco por el desierto, y al no tener agua, el Padre Guatemala le hizo rezar el rosario -devoción mariana, muy estimulada por la Iglesia desde inicios del siglo XIX- y luego cavó en la arena manó agua. En 1938, en el marco de las celebraciones por el centenario de su muerte, el Arzobispo de Lima Farlán de los Godos organizó una peregrinación. Antes se habian hecho algunas esporadicas. Luego vino la construcción de una estructura de concreto en la zona y el azulejo con la imagen del Venerable. Y ciertamente el uso furistico del "Pocito". Todo originado por un testimonio que fue publicitado por el padre Perruquet, a quien le debemos -antes de desaparecer- haber publicado en La Voz de San Jerónimo extractos de los testimonios de la Causa, a inicios del siglo XX, en un intento por reavivar su proceso. Alberto GRIDILLA, Fray José Ramón Rojas de Jesús Maria, Lima 1939; Elias de Carmen PASARELL, Biografia del Venerable Padre José Ramón Rojas de Jesús Maria (1773-1839), en el 90 aniversario de su muerte, Ica, La Voz de San Jerónimo 1929; Enrique PERRUQUET, Fray Ramón Rojas de Jesús Maria, Ica 1930: Carlos PRINCE, Apuntes sobre la vida del Venerable Padre Guatemala Fray José Ramón Rojas de Jesús, Misionero Apostólico y del Colegio de Propaganda Fide de Cristo en la ciudad de Guatemala, fundador y director de la casa de ejercicios de lca, Lima 1892; Narciso B. ROMAN, Relación de las solemnes exequias con que la ciudad de lca honró la memoria del M.R.P. Fr. José Ramón Rojas, Lima 1939 (1era. Ed. 1898); José Miguel VELEZ PICASSO (Jovel), Fray Ramón Rojas, el Padre Guatemala, Lima 1939. Nótese que e grueso de estas publicaciones fue elaborado o en el sexagésimo o en el centenario de su muente. Todos los autores son franciscanos. 
La misión popular y la Tercera Orden eran las armas favoritas de los franciscanos. El fin de la misión era reavivar la fe en cada lugar que un fraile visitaba, como Cristo, con un cayado o a lomo de bestia, invitando a los feligreses a confesarse y recibir los sacramentos. Como decia Pedro Gual (basándose en las enseñanzas de Alfonso María Ligorio, fundador de los Redentoristas): "Ios sermones de misión deben ser más sencillos y menos recargados que las sentencias latinas.... debemos expresarnos de un modo más sencillo y usual, para que el pueblo se haga capaz de lo que se le predica y se conmueva" ${ }^{\prime 2}$. La Tercera Orden, por su parte, era la manera de organizar a los laicos, alrededor del carisma franciscano y preservar en cada lugar, en lo posible, el espíritu de catequesis permanente que se deseaba imprimir. No hubo lugar, en donde trabajaron, donde no se crease una sección de la Tercera Orden ${ }^{33}$.

El 21 de junio de 1819 nació Luisa de la Torre, en Humay, cerca de Pisco. Sus padre murieron siendo ella pequeña, y se crió en su pueblo con su hermana Carmen. Muchos sugieren que trató con el padre Guatemala, que era su confesor y director espiritual. En su pequeña casa enseñó a leer, escribir, auxiliar a los enfermos, alimentar a los caminantes, y a prácticas piadosas. Su hermana Carmen dio clases de costura y bordado a las niñas. La austeridad de su vida reflejó su existencia y su vocación de terciaria. Su casa -que años después sería destruida durante la invasión chilena- estaba a dos cuadras del templo, con un zaguán, dos dormitorios, un oratorio con las imágenes del Niño Jesús, la Virgen de Guadalupe, San Luis Gonzaga y el Ángel de la Guarda; y una pieza pequeña para las disciplinas y los silicios, cocina, corral y cuarto de huéspedes. Murió el 21 de setiembre de 1869, ofreciéndose por una persona que iba a dejar en la orfandad a sus siete niños. Tenía una olla de barro con comida inagotable, según decían, para las decenas de personas que se acercaban a buscar alimentos.

32 Pedro GUAL, Curso de misiones apostólicas, doctrinas y sermones, Barcelona 1884, tomo I, pp. 261-262; Julián HERAS, Los Franciscanos y las misiones populares en el Perú, Madrid, Editorial Cisneros 1983

33 Manuel DOMíngueZ, La Orden Franciscana Seglar en el Perú. Pasado y Presente, Lima, Provincia Franciscana de San Francisco Solano 1992. Asi para 1840 habia secciones de la Tercera Orden en Chincha Alta, Tambo de Mora, Pisco, Ica, Nazca, entre otros lugares de Ica. Recién en 1879 se fundó el Colegio de Propaganda Fidei de Ica.
A su muerte hubo tempranas disputas entre el pueblo y la Iglesia por las limosnas, novenas y misas. Algún testigo aseveró años después que parecía viva a su muerte, y su entierro fue multitudinario ${ }^{34}$. Su partida de defunción dice que: "falleció siendo un prototipo de todas las virtudes, dejando al mundo su ejemplo de santidad, que corroboran en su muerte con muchos signos maravillosos", y se nota allí ya un deseo por buscar su santidad. Su causa fue promovida activamente por los curas de Ica, el Arzobispado de Lima y también por los franciscanos. Su cuerpo está enterrado en el Templo de San Pedro de Humay, y así como el del Padre Guatemala, que se enterró en el Templo de Jesús, José y María de Ica, desde el inicio fue objeto de peregrinaciones y devoción del pueblo, muy bien alentado por las misiones populares y la catequesis franciscanas ${ }^{35}$.

Así pues la religiosidad popular se reavivó y en ello mucho tuvo que ver el estímulo de esa congregación religiosa. Pero ocurrió además en un contexto político y eclesial mar-

\footnotetext{
34 API. Papeles Varios; Medardo ALDUAN CMF, Recuerdos de Luisa de La Torre, la Beatita de Humay, Lima, Editorial Lumen 1941 (2da Edición).

35 Fueron sus confesores reales tanto el sacerdote secular Julián de Enderica (1806-1888), ex párroco de Humay, que a su muerte era canónigo de la Catedral de Lima, y el sacerdote también secular Mauricio Mayuri J. (1841-1919), ex párroco de Humay, y Vicario foráneo de Ica. Al agonizar Luisa, es el influyente canónigo Enderica quien viaja a Humay para presenciar su muerte y organizar sus funerales, y quién testimonia luego "que parecia que estaba viva". Es también él que pide al Arzobispo José Sebastián de Goyeneche abrir el proceso arquidiocesano. En 1871 fue facultado para tal labor de recojo de testimonios, con Andrés Tovar -hermano del futuro Arzobispo de Lima Manuel Tovar- como Juez Ad-hoc. Enderica mismo testimonió el asunto de su muerte extraordinaria, como también que Luisa se le apareció alguna vez que estuvo enfermo en Lima y le ayudó a curarse. También el otro confesor, Mayuri, testimoniará que en 1868, cuando enfermó de viruelas, Luisa se le apareció y le ayudó en su postración. Los franciscanos en el entretanto, con sus misiones populares fueron al parecer tejiendo la historia que era una terciaria franciscana y que el Padre Guadalupe era su confesor. De hecho en los testimonios se recoge uno que dice que antes de morir el Padre Guatemala la visitó en alma y le celebró misa con ángeles y le dio la eucaristia. Enderica reaccionó atestiguando en 1871 en la causa del Padre Guatemala, que Luisa no la conoció, sino que simplemente se le apareció. La voz de San Jerónimo, Ica, diciembre 1924, pp. 349-351; GRIDILLA, Op. Cit., pp. 181-185. Con el tiempo la duda se apoderó y algunos argumentaron que era una terciaria dominica. DOMÍNGUEZ, Op. Cit. En verdad era terciaria mercedaria ALDUAN, Op. Cit., p. 127; Jeffrey KLAIBER, La Iglesia en el Perú, Lima, Pontificia Universidad Católica del Perú 1988, aunque Enderica en la práctica siempre la guió espiritualmente. El rostro conocido de Luisa es obra del pintor Gonzáles Gamarra, quien por indicación de Enderica hizo esta representación con traje terciario, rostro blanco y juvenil y mirada mistica (Compárese esta pintura con las fotos existentes de Melchorita, una terciaria franciscana chinchana del siglo $X(X)$. El canónigo se trajo a Lima la famosa ollita y otros objetos personales. Hubo mucho misterio en el tallecimiento y gran deseo de engrandecerla. Su muerte a los 50 años es tan casual como que el padre Medardo Alduán afirme que cuando en Humay no hubo misa una vez los ángeles le llevaron la eucaristía a Luisa. Paralizado su proceso por años, fue reactivado en 1936, en tiempos del Arzobispo Fartán de los Godos, enviándose el material a Roma en 1949, siendo en 1951 pedido más infornación, llevándola en 1955 el Arzobispo Landázuri Ricketts. Actualmente el obispado de lca ha mostrado interés de continuar con los engorrosos trámites. Leonidas HUAMAN LAOS, "Biografia de Luisa de la Torre (1969)", Boletín Informativo de la Sierva de Dios. Lima, Oficina Central de Propaganda 1994. pp. 1-5. La reactivación del proceso en los años treinta trajo consigo una recuperación de diversos objetos personales de Luisa (ollita, disciplinas, cabellos, etc) y su inhumación en 1939 en el templo de San Pedro de Humay -en 1924 habia ocurrido un traslado.
} 
cado por dos circunstancias imposibles de no entender: en un plano externo, europeo, por la política romana y de las grandes congregaciones religiosas en su lucha contra el liberalismo político, que se graficó en un estímulo muy fuerte a las devociones populares y a la canonización de una serie de personas consideradas mártires durante la pasada Revolución Francesa. En un ambiente marcado por la revolución de 1830 y la lucha liberal y radical contra el papado, el estímulo a la piedad popular y a las tradiciones fue entonces un buen vehículo de acción social contra el descreimiento moderno. En un plano local, luego de guerras civiles cruentas y la reciente experiencia de la Confederación Perú-Boliviana, 1839 y 1840 fueron años de una política restauradora que trató de afirmar los lazos de unidad nacional, y en ese contexto la idea de Cristo y Patria se estimuló en mayor medida. Recordemos que 1839 fue el año del detalle de la reglamentación de repiques de campanas, alusivos a las festividades patrias, y del reglamento para Lima que sancionaba, entre otros, a los transgresores de las faltas a la religión. No es que no existieran normas análogas antes sino que rescatamos ahora la intencionalidad política de las mismas. En 1838 llegaron los franciscanos recoletos con Pedro Gual a la cabeza y para 1840 el obispo Arriaga de Maynas promovió su Propaganda Fidei, auténtico vínculo de Estado e Iglesia por la colonización de la selva. En Lima, para ese año como Arzobispo estuvo el también franciscano Francisco de Sales Arrieta, gran amigo del padre Guatemala, con quien en cartas y otras misivas se probaron una gran franqueza ${ }^{36}$. Curiosamente tras su muerte en 1839 , fueron los franciscanos y este arzobispo los más interesados en promover la santidad de Guatemala. Mientras en Pisco la Beatita de Humay seguía dando comida a los menesterosos y estimulando la piedad. Hay entonces dimensiones políticas y sociales que no debemos descuidar en estos acontecimientos. Como el hecho de que en ese mismo año, se produzca en Roma la beatificación de Martín de Porres y Juan Macias. El momento no pudo ser el más indicado: el Arzobispo de Lima al enterarse, le dio al Presidente Gamarra la noticia y éste publicó el decreto pontificio en medio de la algarabía general y tres horas de campanadas en todos los

36 TOVAR, Op. Cit. templos de Lima. "Esta cristiana grey tuvo noticias... en circunstancias de concluir una guerra", y ciertamente ello indicó el uso político del acontecimiento. La publicación lo hizo el Presidente "en términos tan piadosos, cristiano y afectuoso, que solo su lectura provocaba la piedad, enternecían y hacía rebotar de júbilo los corazones". El 20 de abril de 1840 fueron las solemnes ceremonias en Lima: misas en las parroquias, gran acto en la Catedral, y lo que es más importante, todo un protocolo social que dio oportunidad de mostrarse a las autoridades políticas y eclesiales juntas, en una beatificación, en el caso de Martín de Porres, acaso históricamente antes y después muy a propósito más exaltado que Juan Macías por razones sociales, que reunía al conjunto de la ciudad de Lima, blancos, mestizos y negros, bajo los hábitos de una santidad que era también la santidad de todo un pueblo. Fue interesante además, la utilización nacional de estas celebraciones, con bandera bicolor incluida y discursos exaltadores sobre el Perú, "tierra de santidades". Como entonces se dijo "para que a todos conste, y en los siglos venideros se vea la Religión Católica que profesa esta ilustre República"37.

Probablemente algunos de estos acontecimientos fueron coincidentes, pero fue una muy feliz coincidencia, que probaba para el Estado una estabilidad social que empezaba a tomar cuerpo de cara a una identidad en construcción. Para la Iglesia significaba reafirmar que esa identidad pasaba por lo religioso y católico. La tradición pues, que tanto le interesó resaltar acudió en pos de la práctica presente, para apuntalar a la sociedad. El patrimonio nacional católico se empezó a mostrar con nitidez: el Perú era Católico por hábitos e instituciones, como dijo José de Morales en 1827. Y lo era a través de estas expresiones de religiosidad popular y recogimiento: reafirmándose en la fe y reafirmando a toda una nación en ella, a partir de los legados tradicionales ${ }^{38}$.

\footnotetext{
37 Francisco Sales de ARRIETA, Carta a nuestro Santisimo Padre el señor Gregorio XVI... dándole parte de las solemnidades con que esta ciudad celebró la beatificación de los beatos Juan Macias y Martin de Porres, Lima, Imp. M. Macias 1840, p. 4 y ss.; Carlos Enrique PAZ SOLDAN, Cómo colebró Lima la beatificación de Fray Martín de Porres, Lima 1962.

38 MORALES, Op. Cit., p. 5. Para muchos eclesiásticos la muerte del Padre Guatemala en olor de santidad, implicaba un auténtico triunfo de la Religión sobre el modernismo práctico reinante. GRIDILLA, Op. Cit., p. 195. Otros rescatarán con los años su figura -centroamericana- como un ejemplo de "peruanidad". TOVAR, Op. Cit., p. 302
} 
Además para la Iglesia ello implicaba mostrar un patrimonio distinto del que podía montar el Estado, pero igualmente efectivo. Un patrimonio de santos y devotos, de fe y de esperanzas. Que era el mismo Perú. En el futuro ese discurso, todavía en construcción, por momentos no muy claro, se afirmaría al calor de los debates sociales de la segunda parte del siglo XIX, y en la producción material artística que se gene- rarían en el marco de la bonanza guanera y, luego, en la República Aristocrática.

Fernando Armas Asín

Instituto de Investigación

Escuela Profesional de Turismo y Hotelería

Universidad de San Martin de Porres 